\title{
Informational Value of Dividend Initiations: Impact of Cash Dividends on Share Prices of Manufacturing Companies in Sri Lanka
}

\author{
Krishnamoorthy Charith ${ }^{1}$ \& Andrey Davydenko ${ }^{2}$ \\ ${ }^{1}$ Department of Computer Science and Informatics, Faculty of Applied Sciences, Uva Wellassa University, \\ Badulla, Sri Lanka \\ ${ }^{2}$ Independent Researcher, Antalya, Turkey \\ Correspondence: K. Charith, Faculty of Applied Sciences, Uva Wellassa University, Badulla, Sri Lanka. Tel: \\ 947-1516-4198. E-mail: charithk@uwu.ac.lk
}

Received: December 22, 2020

Accepted: January 8, 2021

Online Published: February 5, 2021

doi:10.5539/ijef.v13n3p13

URL: https://doi.org/10.5539/ijef.v13n3p13

\begin{abstract}
The shareholder wealth consists of dividends and capital gains. The former is considered to be risk averse, whereas the latter is perceived to be risky. The risk return trade-off in these two returns drives the investor preference. The objective of a for-profit organization is to maximize shareholders' wealth, however, disbursing dividends may not always be in the best interest of shareholders. Theoretically, retained earnings increase share prices as firms have more funds to be invested. The objective of the study is to measure the stimulus of cash dividends on share prices. We conduct empirical analysis based on data relating to companies listed on the Colombo Stock Exchange (CSE) under the manufacturing sector. As we show in our literature review, in order to reduce the risk of obtaining spurious results, this analysis requires the use of advanced modelling techniques allowing to model non-stationarity of time series, as well the presence of control variables and lagged variables. The novelty of our study is in the use of advanced modelling and data visualisation techniques (including the 'xdPlot' dataviz framework recently proposed by the authors), especially in application to CSE data. We conduct a thorough exploratory data analysis (EDA) aiming to spot data anomalies and initiate appropriate data transformations. Given the results of EDA and the nature of the data available, we select the Arellano-Bond estimator as the most adequate method for regression analysis. Market Price per share (MPS) termed as the dependent variable, whereas Dividend per Share (DPS) is viewed as the independent variable. The results validated theoretical literature such as signaling effect and bird in hand theory, but questioned some previous empirical studies. The study validated cash dividends as stimulus to investors given the positive relationship between DPS and MPS.
\end{abstract}

Keywords: panel data, dividends, share price, Arellano-Bond estimator, shareholder wealth, Exploratory data analysis (EDA), 'xdPlot' framework

\section{Introduction}

Dividends and capital gains considered being wealth-building tools of any stock market. The investors are attracted given the salient nature of these returns. The risk return trade-off in these two returns drives the investor preference (Gordon, 1959). The former is considered to be risk averse given the returns are materialized forehand, whereas the latter, perceived to be risky, subject to uncertainty given the returns realized later. The distribution of profits can be done in the form of dividends or through repurchasing shares in issue. From one extreme, investing in shares is one of investment options for investors, to another a source of funding for Public Limited Companies (PLCs). So the common stock bridges this gap acting as a common platform.

Shareholder value is the value delivered to the equity owners through dividends and capital gains. If this value is created, particularly over the long term, the share price increases and the company can pay larger cash dividends to shareholders. The ultimate objective of a for-profit organization and investors themselves are to maximize shareholders' wealth. Distribution of created wealth is achieved either through reinvestment in the company, which increases future share value, or through paying dividends. But disbursing dividends, despite it being a wealth-building driver, may not always be in the best interest of shareholders. In keeping with dividend irrelevance theory (Miller \& Modigliani, 1961), retaining dividends helps companies fund investment opportunities fast using internally generated funds. The argument is that said funds are reinvested in positive Net 
Present Value (NPV) projects, thus increasing shareholders' wealth rather than disbursing as dividends. Simply put, such an attempt would increase future share price so as the shareholder wealth. In that context, disbursing dividends has an opportunity cost. The dividend is one of the very many variables that may influence share prices.

On the other hand, firms determine the dividends in keeping with target dividends-to-earnings ratios. It is viewed that maintaining constant dividend payout is important to maximize shareholder wealth, believing dividends are of an informational value (Lintner, 1956). The dividends reflect the financial strength and provide information on a firm's prospects (Black, 1976). If the company is profitable, it should generate positive cash flow, and have enough funds set aside in retained earnings to pay out or increase dividends and fund future investments. The dividends will give a stimulus for investors to buy shares of that particular company. It will increase the demand and increase share price in keeping with typical economic market equilibrium. In keeping with 'Bird in hand theory' of dividends certain investors prefer dividends (Gordon, 1962). After selecting a dividend policy a company should stick to it. The investors that prefer that will come and invest, and people who dislike may opt out. Violating the said policy may send a bad signal to market thus put a firm in jeopardy. In particular, Black (1976) argued that dividend policy is like a puzzle with pieces that don't fit together, the more we look into it more we get confused. One interesting issue here is the question of whether to pay the dividend or not? If yes, then how much dividend is to be paid? The impact of a firm's dividends on its shareholders' wealth is still unresolved.

Managers need to decide whether to finance from internally generated funds (retained earnings) or from external financing (debt or equity). If internally generated funds are used to invest in new projects, the dividend should be cutoff. This may change the firms' existing dividend policy, thus affecting signaling effect. In contrast, disbursing higher dividends would also be an indication that a company is running out of investment options thus disbursing an excess cash pile.

The purpose of this research is to explore available data and to provide the following framework. For investors, we need to give an indication as to which companies are favorable to invest/buy shares. For companies, we need to find a way to send a signal to the market (signaling effect) by way of dividends and persuade investors to buy shares.

The next section contains a literature survey. Then we provide a problem statement and a description of the dataset used for modeling. Then we describe how the modeling was conducted and provide the results obtained. The concluding section summarizes our findings.

\section{Literature Review}

This section attempts to check the validity of both theoretical and empirical literature. The review of empirical literature is carried out with a particular regard to different approaches used for regression modeling. In particular, we pay attention to potential methodological flaws, such as spurious correlation.

\subsection{Dividend Irrelevance Theory}

Miller and Modigliani (1961) theorized that dividend policy has no impact on stock price and cost of capital, resultantly the dividend policy of a firm is irrelevant for shareholders wealth in keeping with perfect capital market assumptions (Ang \& Ciccone, 2011). Prior to that, Modigliani and Miller (1958) detailed the capital structure, where they showed that the firm value is not determined by the composition of debt and equity of the capital structure. Given a choice between financing new projects with retained earnings or with new equity, firm managers should be indifferent. However the capital structure and dividend policy is interlinked. The dividends may reduce the firm's ability to fund investment projects thereby needing to source funds either through debt or equity. Accordingly, the capital structure irrelevance as well as dividend irrelevance argues that firm value is not affected by them. It is noteworthy Modigliani and Miller (1958) capital structure theory forms the foundation for dividend irrelevance theory. The conditions and assumptions required to make dividends irrelevant are also the ones that make internal financing equivalent to external financing. Miller and Modigliani (1961) theory went on to say investors are indifferent between dividends and capital gains. The argument as such if the dividend is not paid it is reinvested and reflected in future share prices as a capital gain, which is equal to the present value of dividend sacrificed. If a firm is not keeping up to investors' expectations the investors can opt out and realize their cash, or sometimes firms offer share repurchases. Despite it being criticized for its assumptions, which do not hold in the real world, it formed a solid foundation for further research and theories discussed below.

Ang and Ciccone (2011) in their publication mentioned Black and Scholes (1974) find no significant relationship between the dividends and stock prices, further providing evidence for irrelevance. According to Farrukh et al. 
(2017), the results proposed by Pilotte (1992) suggested that firms that distribute more dividends, usually exhibit less appreciation in stock price. However, Ang and Ciccone (2011) in their publication mentioned DeAngelo and DeAngelo (2006, p. 296) openly criticized Modigliani and Miller arguments on dividends irrelevance is of "trivial import."

\subsection{Dividend Relevance Theory}

The view is supported by Lintner (1956) saying companies prefer to maintain dividends or smooth dividends over time. According to Gordon (1959) and Walter (1963), the dividend policy almost always affects the value of the enterprise, and the investment policy of a firm cannot be separated from its dividend policy. These authors provide evidence that dividends have an impact on share prices when capital markets are imperfect. The firms which pay dividends to their shareholders are considered positively and bear a good image in their minds. Gordon (1959) in his legendary model, consisting of variables such as dividends and discount rate, highlighted that increasing dividends increases the share prices. The dividend relevance theory relaxes the assumption of perfect capital markets and rational investors. According to dividend relevance theory the dividends are of an informational value. Declaration of dividend can be justified in the context of signaling theory, agency theory and clientele theory discussed below. It is noteworthy that all these theories focus on market imperfections.

\subsection{Bird-in-Hand Theory}

In response to Dividend irrelevance theory Miller and Modigliani (1961), the 'bird in hand' theory was introduced by Gordon (1962). According to the 'bird in the hand' theory, investors prefer dividends (cash receipts which are certain) to retained earnings (which are less certain, affected by poor future performance). Also Gordon (1962) argues that lower dividend payouts and higher earnings retention ratios lead to higher costs of equity because of the increased risk of the future cash flows. Higher cost of equity leads to lower prices in Gordon's valuation model. Gordon $(1959,1962)$ revealed that increasing dividends increases share price and reduces the discount rate. Lintner (1956) and Gordon (1959) propose that investor is always a risk-avoider and desires to obtain dividend instead of capital gains in future. Unlike in dividend irrelevance theory, here investors have a preference. It was evident that firms should set a large dividend payout ratio to maximize firm share value in keeping with above research.

\subsection{Clientele Effect}

In support of dividend relevance theory, some research suggests firm's share price reacts to changes in dividend policies. There are several types of dividend policy such as stable dividend policy, constant dividend policy and residual dividend policy. Irrespective of the dividend policy, if one policy is selected the firms should stick it. The investors who like the said policy are concentrated around it, whereas those that dislike opt out. Accordingly, an investor makes a decision on the basis of the firm's dividend policy. When a firm changes dividend policy, investors make their investment decisions accordingly. Shareholders and investors purchase the shares of those firms whose dividend policy satisfy their needs. As per Miller and Modigliani (1961) each corporation attracts investors referring to its payout ratio.

The burden of tax drives the investor preference between capital gain and dividends. Farrar and Selwyn (1967) argue that with higher taxes on personal income than on capital gains all firms should maintain a zero dividend policy. Major shareholders who are in the higher tax brackets would prefer the capital gains due to relative tax disadvantage of dividends (Brennan, 1970).

There are different kinds of clienteles. Tax-based clienteles are related to signaling (Ang \& Ciccone, 2011). As Shefrin and Statman (1984) noted, investors may prefer cash dividends for psychological reasons. According to John and Williams (1985), clienteles such as widows, senior citizens, and financial institutions are concentrated around dividend-paying firms.

\subsection{Signaling Effect}

In response to Miller and Modigliani (1961), Asquith and Mullins (1983) revealed dividend announcements give rise to increase in share prices. Ross (1977) and Solomon (1963) depicted that firms significantly increasing dividend payments lead to increase in share prices, whereas those firms that omitted or reduce dividend payments depicted a decline. Pettit $(1972,1976)$ provided evidence that change in dividend announcements signals information to the market, both negative and positive. However, in presence of information asymmetry, Bhattacharya (1979), John and Williams (1985) and Miller and Rock (1985) argued better informed insiders use the dividend policy as a costly signal to convey their firm's future prospect to less informed outsiders. Maditinos et al. (2007) provided strong evidence that individual investors in Greece want dividends and companies pay healthy dividends relatively appear to be honest, reliable and less influenced by accounting manipulations. 
A major issue with signaling arguments is figuring out exactly what the signal is. Unfortunately, the evidence supporting signaling is mixed (Ang \& Ciccone, 2011). A firm that does not pay dividends can also demonstrate confidence that it has attractive projects to invest which is not possible if the dividends are paid (Black, 1976). However it is viewed that dividends provide a signal to the market of performance and future prospects of the company. In keeping with Lintner (1956) the firms trying to sustain a certain level of dividends irrespective of the earnings are lower or higher. In general, firms keep a cushion against lower earnings to sustain the level of dividends and not to disturb the market signals. The fluctuation of dividends may be a bad signal to investors.

\subsection{Agency Theory}

This theory has focused on conflict of interest between management and shareholders. The main task of a manager is to enhance the wealth of shareholders and manage the business properly. The agency issue occurs when there is an excess cash flow in the organization and they have to invest in profitable projects but they utilize the cash in their own interest instead of shareholders. The reason being the managers are reluctant to accept high return projects and interested in short term returns to secure their perks rather than accepting projects of long-term interest to shareholders. So shareholders have to keep an eye on managers. And the cost that arises on monitoring of managers is agency cost. Many researches have stated in their research work that dividends are important in minimizing the agency cost as it acts as compensation. Easterbrook (1984) pointed out monitoring and the risk-aversion problems are less serious if the firm is constantly in the capital market to obtain new capital. When a company issues new securities its operations will be reviewed by an investment banker and by the buyers/investors of said securities.

\subsection{Gaps in Empirical Studies}

In order to test the above theories it is required to conduct statistical modelling based on real data. This task is, however, not straightforward due to the complex features of relevant datasets. Below we provide an overview of existing empirical research, identify gaps and limitations we found in existing literature, and emphasize the need for additional research in order to make empirical results more reliable and avoid erroneous conclusions. In particular, we identify potential methodological issues, such as spurious correlation, endogeneity assumption violations, unaccounted non-stationarity, and over-fitting. Generally, our analysis of empirical literature shows that there have been different conclusions arrived at using different methodologies. Moreover, different studies relate to different countries, company types, and time intervals so it's hard to generalize the results. In our brief overview below we will look at a number of studies with a particular regard to signaling theory, as it better relates to the context of this research.

In order to study the effects described above, empirical studies usually are based on so-called 'panel data' instead of looking at individual companies. For datasets having a panel design we assume that for a set of objects (in our case, companies) quantities of interest are measured over time. This approach gives "more informative data, more variability, less collinearity among the variables, more degrees of freedom and more efficiency." (Baltagi, 2001, p. 6). However, panel data features individual heterogeneity and time effect. These features require very careful testing for modelling assumptions. For example, stationarity is a prerequisite for applying statistical tests for dependency in order to avoid spurious correlation. Variables should therefore be tested for stationary and transformed accordingly, when necessary (Farrukh et al., 2017; Lashgari \& Ahmadi, 2014).

Some studies tried the ordinary least square (OLS) method (e.g., Azhagaiah \& Priya, 2008; Hunjra et al., 2014; Hussainey et al., 2011). However, since this approach does not take the individual heterogeneity and time effets into account, the results of these studies should be treated with caution (Ali et al., 2011). Many researchers (e.g., Ali et al., 2011; Al-Shawawreh, 2014; Dewasiri \& Banda, 2015; Farrukh et al., 2017; Lashgari \& Ahmadi, 2014; Memon et al., 2017) utilized special panel data methods, such as fixed effects (FE) and/or random effects (RE). While these methods help model data heterogeneity, the presence of non-stationary time series may result in erroneous conclusions due to spurious correlation. Regression analysis may then generate high $\mathrm{R}^{2}$ values even when there is no cause-effect relationship between the dependent and independent variables. This problem may be partly fixed by using first differences in order to make time series stationary. Assuming all variables are stationary we can also test the hypothesis if past values of both the dependent variable and independent variables have a significant effect on the present value of the dependent variable. This procedure is known as testing for Granger-causality (G-causality) and was applied in a number of studies in the given context (see Timmermann, 1994; Dewasiri \& Banda, 2015). The use of differenced series, however, reduces the ability of models to take into account long-term effects (Engle \& Granger, 1987). Therefore dynamic panel data models are more relevant (such as those used, e.g., by de Wet \& Mpinda, 2013; Suwanhirunkul \& Masih, 2018).

One important part of building regression models in the given context is the choice of control variables in order 
to reduce the risk of unexplained variables. Various control variables such as size, growth, earnings, leverage were used by various researchers depending on the nature of the research objectives (Ahmad et al., 2018; Al-Shawawreh, 2014; Dewasiri \& Banda, 2015; Memon et al., 2017). Miller and Modigliani (1961) argue that the value of the firm depends on the firm's earnings, which result from its investment policy. Hence companies should invest excess funds in positive net present value projects instead of paying them out to shareholders. Auret and De Villiers (2000) using a multiple linear regression technique, found that EPS (as a control variable) had greater explanatory power than the DPS in the explanation of share price. Here it is important to mention that control variables should not relate to the dependent variable, otherwise it may cause spurious correlation results. For example, some studies used Dividend Yield (DY) as a control variable (e.g., Hussainey et al., 2011; Memon, 2017; Harshapriya, 2016). In some cases a positive relation is found between DY and stock price was found. However, since the formula to calculate DY uses MPS directly, these models are subject to endogeneity problems. As an example, high R-squared values (as high as $95.4 \%$ similar to that of Memon et al., 2017) is suspicious and may be due to spurious correlation.

Most advanced studies have been based on dynamic panel data models with careful selection of control variables. de Wet and Mpinda (2013) used dynamic modelling for panel data allowing to take into account lagged endogenous variables (more specifically, the panel vector error correction model, PVECM, was applied). The results suggest that there is a long-run relationship between the DPS and the MPS while EPS do not have a significant impact on the market price per share. All variables were found to be non-stationary, I(1), and then cointegration tests proved the long run cointegration of all panel series. Later Persson (2015) also used PVECM to unearth the short and long term interdependencies between share prices and dividend. The results show that there is a bi-directional long-term relationship as well as a short term bidirectional relationship between stock prices and dividends.

A number of additional studies also implied dynamic panel data models arriving at similar results (Nirmala et al., 2014; Suwanhirunkul \& Masih, 2018; Hamid et al., 2017; Abdullah et al., 2018). The results indicate that dividend payout has a significant positive impact on share prices and show that dynamic panel data models give more credible results compared to fixed and random effects models.

However, according to our understanding, a similar study which used dynamic panel data models, notably the Arellano-Bond estimator, was not found in the Sri Lankan context. Our study wishes to increase informational content of the dividends as well as lagged market prices, thus aiding the investors to arrive at better informed decisions. As we found, most finance researchers are trapped in traditional panel models like FE, RE, and OLS. The idea of our work is to dig deep into data properties, apply data visualizations to spot anomalies and initiate necessary transformations, use dynamic panel data models to perform regression modelling, and use G-causality tests to back our findings. Some results described in this paper were earlier presented at the International Research Conference of Uva Wellassa University - 2020 (IRCUWU-2020) (see Charith \& Davydenko, 2020b, 2020c; Davydenko \& Charith, 2020a, 2020b).

One gap we found in existing studies is that no studies provided a comprehensive exploratory data analysis (EDA) for the data used (confining the EDA to providing tabulated descriptive statistics). However, EDA is a prerequisite for obtaining credible results in statistical modelling. In our study we employed a framework for visual analysis of panel data proposed in (Davydenko \& Charith, 2020a). The visual analysis aimed to improve overall transparency of our research. We believe the application of the data visualisation framework may present interest to researchers who wish to conduct similar analysis.

Finally, we'd like to mention that for most studies the datasets used were not readily available. In order to ensure reproducibility and transparency of our results and to allow other researchers to try alternative methods, we made the dataset used and its detailed description publically available via the 'Figshare' platform, see (Charith \& Davydenko, 2020a).

\section{Problem Statement, Research Objectives and Questions}

\subsection{Problem Statement}

As discussed above, companies find it difficult to get the right balance between disbursing dividends and retaining dividends, to fund future investments, given the stimulus contained in dividends. However, both these approaches may increase MPS thus resulting in a trade-off. Investing in shares is one of the many options available for investors. Firms face competition, with other investment opportunities, to attract investors in keeping with the risk-return trade-off and their risk appetite. Shares are considered to be the most risky source of finance so the return should also be high to compensate (specifically through dividends) said risk. Rational investors are concerned about their optimal level of benefit or utility and always compare the prevailing 
investment options before an investment decision is made.

The results in this research contribute to shareholder information, the impact of dividends on share prices, thus contributing to decision making literature of investors. Efficient Market Hypothesis (EMH) details that share prices reflect all information (Fama, 1970). Strong market form EMH makes it impossible for investors to purchase undervalued stocks or sell stocks for inflated prices. It is impossible to gain returns through expert stock selection or market timing. The only way to obtain higher returns is by purchasing riskier investments/shares. So under no circumstances investors can outsmart other investors as all the information is available in the public domain. As per EMH, a strong form of market assumes that current stock prices fully reflect all public and private information. However, this study attempts to unearth the information content in dividends to be used in decision making. Failure to understand the real informational value of past shares prices challenges the status of the stock market of it being a strong form of market.

\subsection{Objective of the Study}

Overall objective of this research is to explore the extent of association between cash dividends and share market price (shareholders wealth). The study expects to check the validity of both theoretical and empirical literature in the context of the above objective. However, substantial empirical evidence is not found in a much needed frontier market like Sri Lanka. This paper attempts to use accurate methodology, given the nature of data properties, as appropriate methodology is key in finance research.

Specific objectives of this research are:

- to unearth the short and long term impact of dividends on shares prices;

- to investigate the impact of lagged share prices;

- to provide a guideline for companies to pursue the right dividend policy;

- to provide a guideline for existing and prospective investors to make informed decisions.

\subsection{Research Questions}

In keeping with the primary objective of exploring the extent of association between cash dividends and share market price (shareholders wealth), the following research questions are thereby formulated (at a company level):

- Is MPS associated with current and previous DPS values?

- Is MPS associated with previous MPS values?

\subsection{Importance and Benefits of the Study}

Facilitating investment activity is the need of the hour in any government given the current global economic turmoil. Higher share prices persuade investors to buy shares thus increasing the liquidity and promoting investment activity. The dividends will give a stimulus for investors to buy shares of a particular company. It will increase the demand, increase the share prices thereby promoting investing activity. The study provides a framework to investors as to how their wealth is maximized.

This study gives a guideline to companies to select the most appropriate dividend policy in keeping with investors' preference and ultimate objective of maximizing shareholder wealth. So the companies can get the right balance between disbursing dividends and retaining dividends although both strategies are wealth building tools.

\section{Research Dataset}

We conducted a panel study using data obtained through annual reports from 22 companies from 2011 to 2019 listed on the Colombo Stock Exchange under the manufacturing sector. The dataset contains 198 observations and relates to companies that were paying dividends on a regular basis only. Following Farrukh et al. (2017), we excluded companies not paying dividends for more than three years. Several companies were excluded due to lack of data in order to make the panel balanced for further analysis. Table 1 shows the variables used for the analysis. The currency used is Rs, Sri Lankan rupee. The dataset is available online via the 'Figshare' platform (see Charith \& Davydenko, 2020a). 
Table 1. Research dataset variables

\begin{tabular}{|c|c|c|}
\hline variable & short name & description \\
\hline MPS (Dependent variable) & MPS & Market price per share (obtained from stock exchange) \\
\hline $\begin{array}{c}\text { Dividend per share } \\
\text { (independent variable) }\end{array}$ & DPS & Dividend paid per share in respective company per year \\
\hline $\begin{array}{l}\text { Dividend payout ratio } \\
\text { (control variable) }\end{array}$ & DPO & Dividend per share/Earnings per share \\
\hline $\begin{array}{l}\text { Lagged Earnings per share } \\
\text { (control variable) }\end{array}$ & EPS_lag & Earnings/No. of shares in issue \\
\hline $\begin{array}{l}\text { Lagged Logarithm of sales } \\
\quad \text { (control variable) }\end{array}$ & LOGS_lag & This is the (natural) logarithm of sales. Used to measure company size \\
\hline $\begin{array}{l}\text { Lagged Debt Ratio } \\
\text { (control variable) }\end{array}$ & DR_lag & Total Debt/Total assets \\
\hline $\begin{array}{l}\text { Lagged Gearing ratio } \\
\text { (control variable) }\end{array}$ & GR_lag & Total Debt/Equity \\
\hline $\begin{array}{l}\text { Lagged Growth of the Company } \\
\text { (control variable) }\end{array}$ & GRA_lag & GROWTH $=$ Change in Assets $/$ Total Assets \\
\hline
\end{tabular}

\section{Modeling}

\subsection{Exploratory Data Analysis (EDA)}

In order to select a suitable approach for modeling, it is needed to explore the features of available data and check for potential data issues. These tasks are performed using exploratory data analysis (EDA). For panel data, EDA is crucial as panel data modeling relies on the use of sophisticated models and tests with many assumptions.

In this paper we apply a framework for EDA for panel data (called 'xdPlot' by the authors) proposed by (Davydenko \& Charith, 2020a, 2020b). The framework aims to address the following tasks 1) to identify potential data flaws, 2) to detect missing cases, 3) to explore correlations and distributions, 4) to evaluate non-stationarity, 5) to detect the need for data transformations. To solve the above tasks, the framework contains a set of tools (including spaghetti plots, dotplots, and scatterplots for multi-categorical data) to represent panel data, plotting rules for effective data visualisation, and a corresponding workflow to perform panel data analysis prior to regression modelling. To ensure effective analysis, the framework uses the principle of optimizing the ink-to-data ratio (Tufte, 2010), see (Davydenko \& Charith, 2020c) for more details.

We first present tabulated summary statistics, in a similar way to existing studies. Then we apply the EDA framework to make sure data is appropriate for further modelling. After that we apply unit root tests to confirm EDA findings about non-stationarity before proceeding to G-causality tests and regression modeling.

\subsubsection{Summary Statistics}

Table 2 shows summary statistics for the dataset described in Section 4.

Table 2. Data summary

\begin{tabular}{|c|c|c|c|c|c|c|c|c|}
\hline variable & cases & mean & median & $\min$ & $\max$ & range & skew & kurtosis \\
\hline com & 198 & 14.68 & 16.5 & 1 & 29 & 28 & -0.07 & -1.35 \\
\hline Year & 198 & 2015 & 2015 & 2011 & 2019 & 8 & 0 & -1.25 \\
\hline MPS & 198 & 64.86 & 62.55 & 1.6 & 258.1 & 256.5 & 0.86 & 1.04 \\
\hline DPS & 198 & 2.43 & 1.5 & 0 & 18 & 18 & 2.39 & 7.25 \\
\hline DPO & 198 & 0.46 & 0.35 & -0.11 & 8.93 & 9.04 & 8.66 & 97.97 \\
\hline EPS_lag & 176 & 7.53 & 4.1 & -14.61 & 49.65 & 64.26 & 1.56 & 3.7 \\
\hline LOGS_lag & 154 & 9.28 & 9.32 & 8.02 & 10.39 & 2.37 & -0.26 & -0.39 \\
\hline DR_lag & 154 & 0.18 & 0.16 & 0 & 0.5 & 0.5 & 0.25 & -0.95 \\
\hline GR_lag & 154 & 0.35 & 0.3 & 0 & 1.81 & 1.81 & 1.19 & 2.47 \\
\hline GRA lag & 154 & 0.1 & 0.07 & -0.31 & 0.75 & 1.06 & 0.88 & 2.04 \\
\hline
\end{tabular}

Table 2 shows that there are zero DPS cases, but shows no obvious data anomalies. While the table gives some 
overview of the data, it does not allow to fully explore data features and detect potential data flaws. In order to obtain a better understanding of the data, we used a set of graphical tools (additional EDA methods) as described below.

\subsubsection{Correlation Plots and Suitable Data Transformations}

To describe the distribution of MPS cases and explore autoregressive dependencies in MPS series we constructed a scatterplot shown on Figure 1. Each company is coded using individual color and mark. We used standard marks and colors implemented in 'ggplot2' R-package (Wickham, 2016) to code panels. Figure 1 shows that the variance of MPS is not constant and depends on MPS_lag.

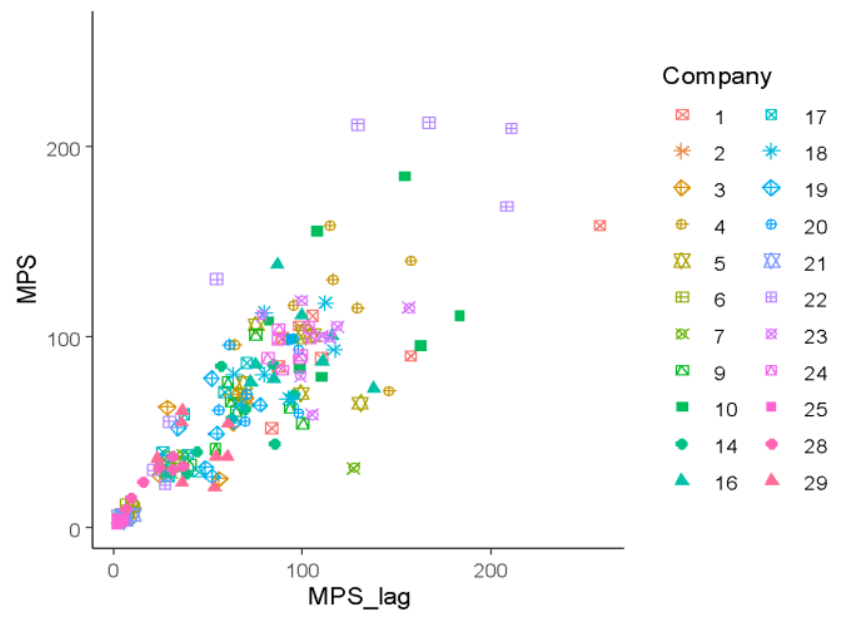

Figure 1. MPS vs MPS_lag scatterplot for raw data

Note. Standard colors and marks from 'ggplot2' R-package were used to represent different companies. The graph reveals heteroscedasticity: the variance of MPS depends on MPS_lag, which suggests the need for data transformations.

One well-known approach here is log-transformation. For example, Olaniyi (2019) emphasized that logarithmic transformation helps mitigate differences in variables across firms and reduce heteroskedasticity with reference to studies by Uusitalo (2012) and Zhu and Tian (2009). This transformation was also used by de Wet and Mpinda (2013). One additional advantage of log-transformations is that coefficients can be interpreted as elasticities (de Wet \& Mpinda, 2013).

Figure 2 shows that the log-transformation helps achieve homoscedasticity (the natural logarithm was used). Clearly, $\log$ (MPS) is more suitable for parametric modeling. Figure 2 shows no potential outliers and reveals linear linear dependencies, which is an important finding.

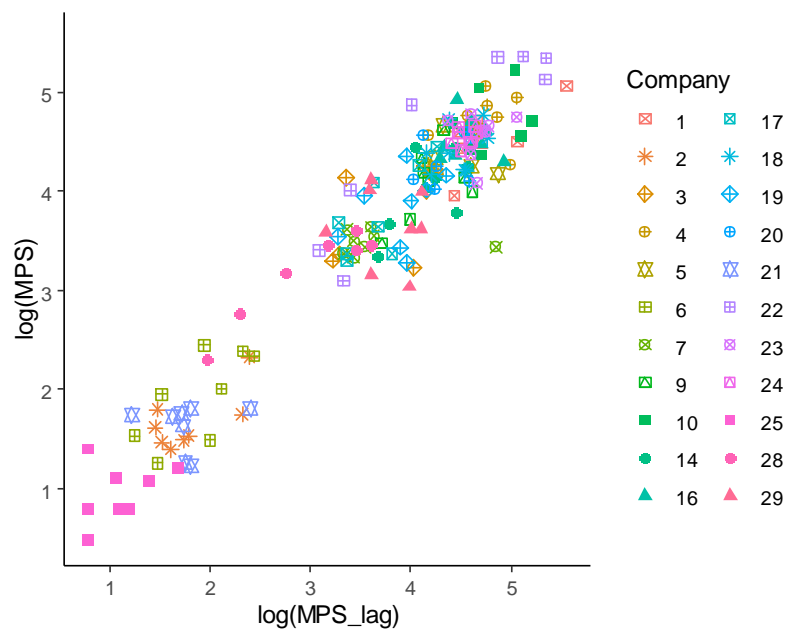

Figure 2. $\log$ (MPS) vs $\log$ (MPS_lag) scatterplot

Note. Applying the log-transformation helped remove heteroscedasticity shown on Figure1 and made data more appropriate for statistical modeling. 
The scatter plot for MPS vs DPS prompts the need for data transformations as well (Figure 3). The skewed nature and heteroskedasticity is evident in data distribution.

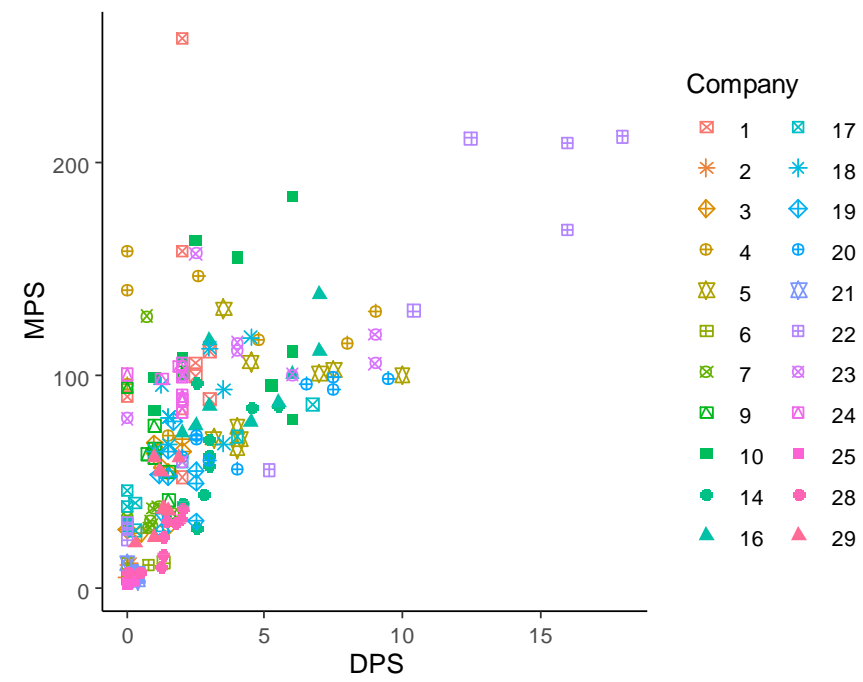

Figure 3. MPS vs DPS scatterplot for raw data

Note. The graph reveals heteroscedasticity (similarly, to Figure 1), however, since DPS values contain 0's, data transformation is not straightforward.

Although taking logs can be done for MPS, it is not possible to take logs of DPS directly due to the presence of 0 's. One approach here is to add a (relatively) small number to DPS. E.g., we can use log[DPS +0.025$]$ instead of $\log (\mathrm{DPS})$, where 0.025 was found as $\min (\mathrm{DPS}) / 2$. However, this approach did not work for our data as the replaced cases did not fit well with the rest of data (See Figure 4). We tried another transformation where 0's were replaced with $\min (\mathrm{DPS}) / 2$ for each company, and created a new variable called DPS2 (see Davydenko \& Chairth, 2020a, for more details about this approach). Figure 5 shows correlation between $\log (\mathrm{MPS})$ and $\log (\mathrm{DPS} 2)$. We use these variables to proceed with further formal statistical tests and models since these transformations helped achieve homoscedasticity. We applied logs to control variables as well (Figure 6).

This step helped identify plausible data transformations and did not reveal any serious data problems for the transformed variables.

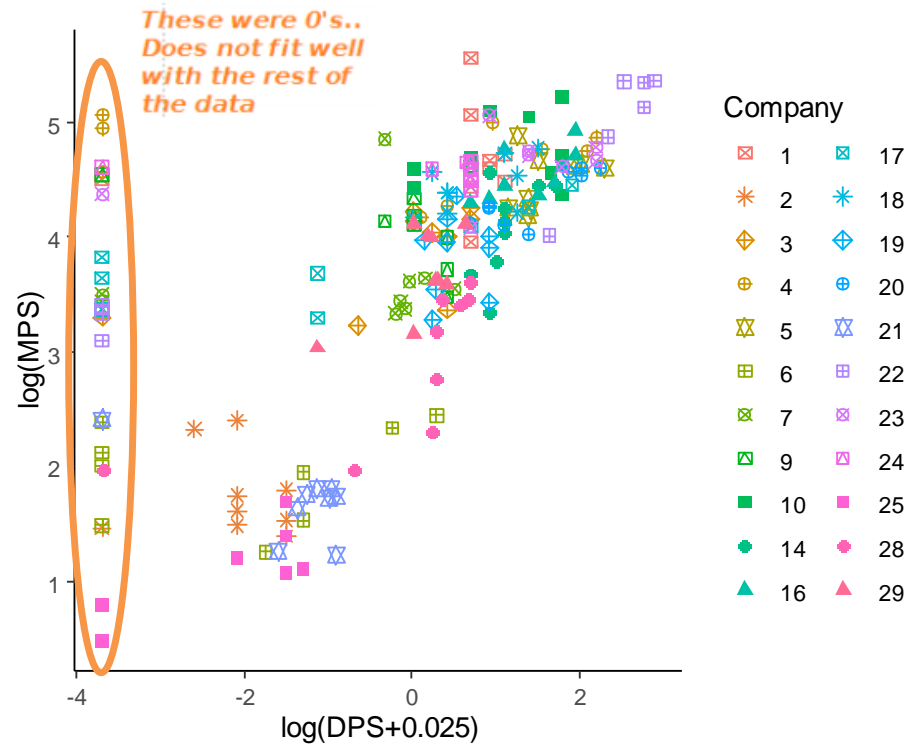

Figure 4. $\log (\mathrm{MPS})$ vs $\log (\mathrm{DPS}+\min (\mathrm{DPS}) / 2)$ scatterplot

Note. By comparing Figure 4 with Figure 3 it can be seen that while log-transformation helps reduce heteroscedasticity, simply adding a (relatively) small number to DPS values gives points that do not fit well with the rest of the data. 


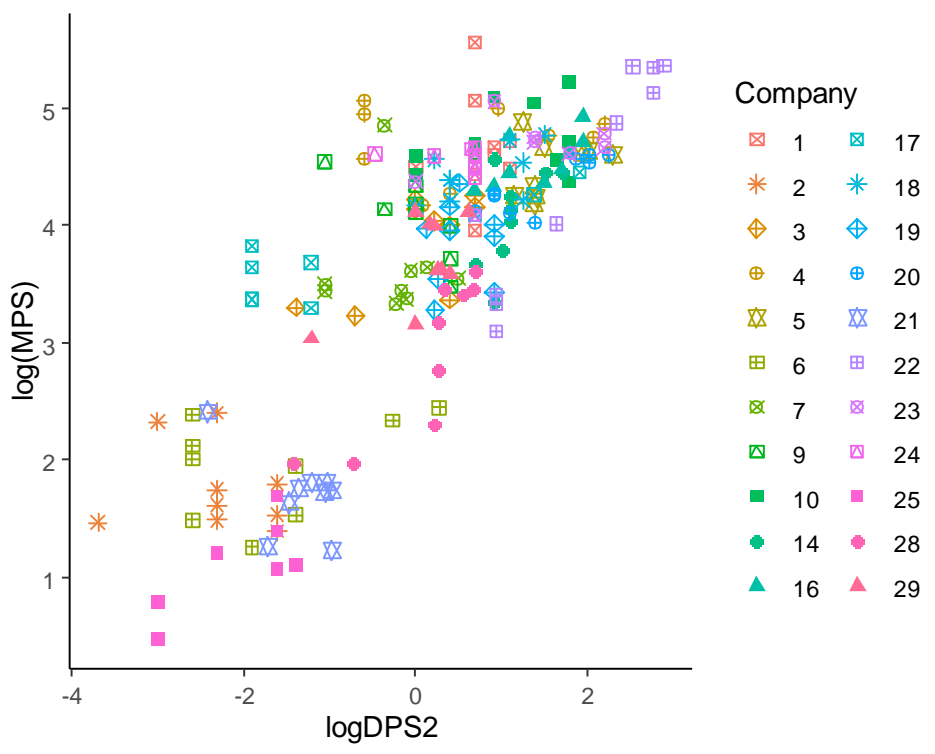

Figure 5. $\log$ (MPS) vs $\log$ (DPS2) scatterplot

Note. The new approach to transformation helped improve data features. The graph reveals no evident data problems.

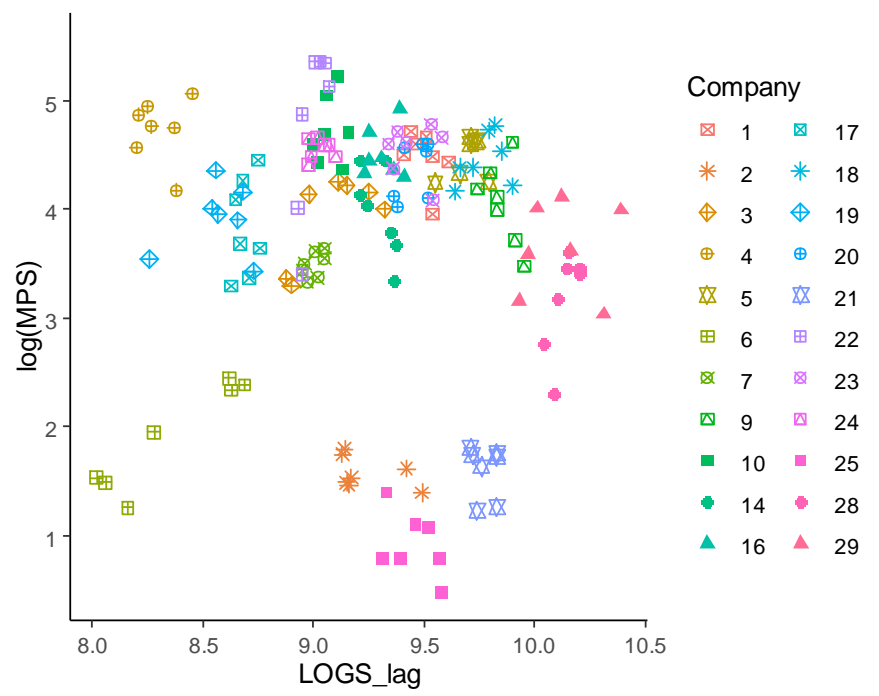

Figure 6. $\log$ (MPS) vs LOGS_lag scatterplot showing no evident data problems

\subsubsection{Spaghetti Plots}

Since temporal dependencies may lead to spurious correlation, we apply visual tools to detect non-stationarity. In accordance with the EDA workflow, we use spaghetti plots (Figure 7) to detect potential data flaws and temporal dependencies. These graphs revealed suspected trends; however this is subject to formal stationary tests we apply in further sections. The differences between levels on the graph, created for log variables, have much lower variance compared to the graph for the raw data, which is better for parametric modeling. 


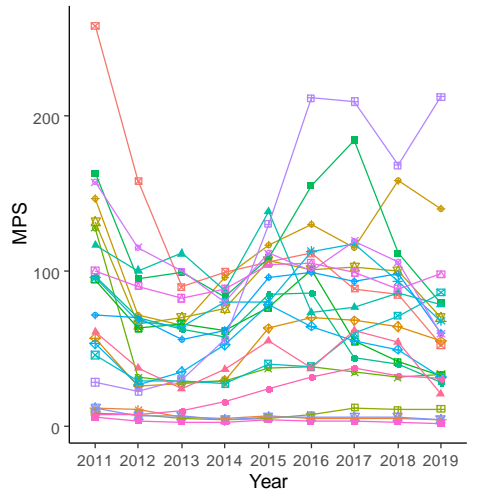

Company

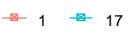

* $2 * 18$

$\leftrightarrow 3 \nrightarrow 19$

$\rightarrow-4 \rightarrow 20$

世 5 - 21

巴- $6 \quad-22$

* 7 * 23

- $9 \quad-24$

$-10-25$

$-14 \rightarrow 28$

$₫ 16 \rightarrow 29$

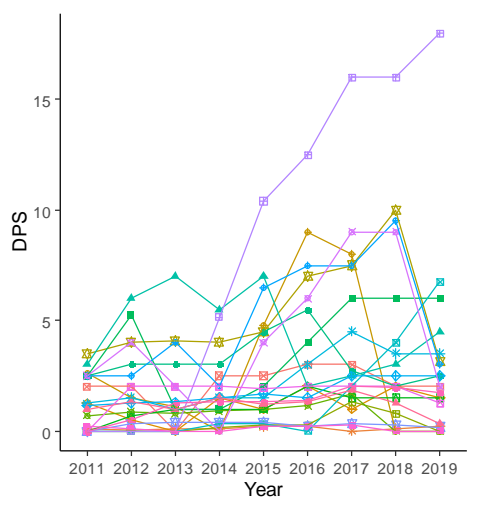

Company

$\begin{array}{lll}-1 & -4 & -17\end{array}$

* $2 * 18$

$\rightarrow 3 \multimap 19$

$\rightarrow-4 \rightarrow 20$

$5-21$

世 6 - 22

$\approx 7 * 23$

- $9-24$

$-10-25$

$-14 \rightarrow 28$

$₫ 16-29$

Year
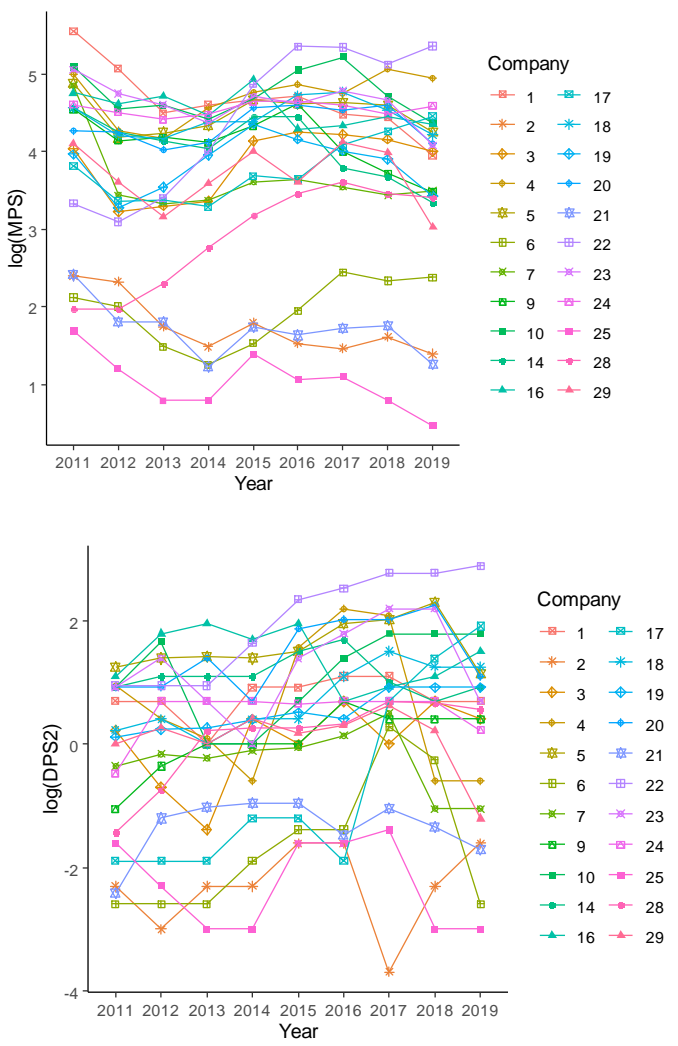

Figure 7. Spaghetti plots for MPS, $\log (\mathrm{MPS})$, DPS, and $\log (\mathrm{DPS} 2)$ showing the behavior of variables over years

\subsection{Additional Variables Introduced After Data Transformations}

As a result of the data transformations the following variables were added to the initial dataset described in Section 4:

- $\quad \log (\mathrm{MPS})$ - log-transformed MPS;

- $\log (\mathrm{DPS} 2)$ - $\log$-transformed DPS (zero cases are replaced with ' $\min (\mathrm{DPS}) / 2$ for each company', as prescribed in Section 5.1.2).

\subsection{Tests for Stationarity}

The stationary tests are performed with a particular regard to Fisher-augmented Dickey-Fuller (ADF) and Fisher-Phillips-Perron (PP) test, proposed by Maddala and Wu (1999). The results of the test are given in Table 3. We used eViews (IHS Global Inc., 2019) to produce the results.

Table 3. Panel unit root tests (eViews output)

\begin{tabular}{|c|c|c|c|c|c|c|c|}
\hline \multirow[t]{2}{*}{ test type } & MPS & DPS & $\log ($ MPS $)$ & $\log ($ DPS2) & DPO & LOGS & $\operatorname{diff(LOGS)}$ \\
\hline & P-value & P-value & P-value & P-value & P-value & P-value & P-value \\
\hline \multicolumn{8}{|l|}{ Summary } \\
\hline Levin, Lin \& Chu $t^{*}$ & 0.0000 & 0.0000 & 0.0000 & 0.0000 & 0.0000 & 0.0000 & 0.0000 \\
\hline Breitung t-stat & NA & NA & NA & NA & NA & 0.0276 & 0.0000 \\
\hline \multicolumn{8}{|c|}{ Null: Unit root (assumes common unit root process) } \\
\hline Im, Pesaran and Shin W-stat & 0.0114 & 0.0376 & 0.0255 & 0.0075 & 0.0000 & 0.2926 & 0.0000 \\
\hline ADF - Fisher Chi-square & 0.0035 & 0.0049 & 0.0162 & 0.0028 & 0.0000 & 0.0609 & 0.0000 \\
\hline PP - Fisher Chi-square & 0.0000 & 0.0108 & 0.0125 & 0.0002 & 0.0000 & 0.0000 & 0.0000 \\
\hline \multicolumn{8}{|c|}{ Null: Unit root (assumes individual unit root process) } \\
\hline \multicolumn{8}{|l|}{ Hadri } \\
\hline Hadri Z-stat & 0.0000 & 0.0000 & 0.0000 & 0.0000 & 0.0000 & 0.0000 & 0.0000 \\
\hline Heteroscedastic Consistent Z-stat & 0.0000 & 0.0000 & 0.0000 & 0.0000 & 0.0000 & 0.0000 & 0.0000 \\
\hline Null Hypothesis: Stationary & & & & & & & \\
\hline
\end{tabular}


The three variables were of the same order except for LOGS. As a result the variables which are stationary used in further statistical tests without any further transformation such as differencing. Upon conclusion that both $\log ($ MPS $)$ and $\log$ (DPS2) are stationary at levels the study proceeded to G-causality test. It is noteworthy that LOGS, a control variable, is not stationary at level according to results depicted in Table 3 as for some tests LOGS held results to contrary. However, the p-values of first differenced values of LOGS, which reflected under diff(LOGS) in Table 3, revealed LOGS is I(1). In conclusion, panel unit root tests revealed that none of the variables are $\mathrm{I}(2)$ which is a prerequisite of the Arellano-Bond Estimator which we will use for regression analysis.

\subsection{Tests for G-Causality}

We used panel G-causality tests to investigate the short-term causality of variables. Tests were applied for both raw data and log-transformed data, calculated using the eViews (IHS Global Inc., 2019). Results are presented in Tables 4 and 5. There is a short-run causality from DPS to MPS as the null hypothesis is rejected given the p-value is less than 0.05. Similarly, variables $\log$ (DPS) and $\log ($ MPS) also depicted a short run causality. However, it is noteworthy that both these variables depicted a bidirectional relationship (Table 4). Similar results, bidirectional short run causality between MPS and DPS, were arrived at by Nirmala et al. (2014).

The LOGS_lag also depicted a short run causality towards MPS as the null hypothesis is rejected for $\mathrm{p}$-values being less than $0.05(0.0110)$. However, there is a unidirectional relationship between MPS and LOGS, which is G-cause MPS whereas MPS does not G-cause LOGS_lag.

Table 4. Pairwise G-causality Tests: Raw data

\begin{tabular}{lccr}
\hline Sample: 20112019 & & & \\
Lags: 1 & & & \\
\hline Null Hypothesis: & Obs & F-Statistic & Prob. \\
\hline DPS does not Granger Cause MPS & & 176.5342 & 0.0002 \\
MPS does not Granger Cause DPS & & 5.05537 & 0.0258 \\
\hline
\end{tabular}

Table 5. Pairwise G-causality Tests: Log-transformed data

\begin{tabular}{|c|c|c|c|}
\hline \multicolumn{4}{|l|}{ Sample: 20112019} \\
\hline \multicolumn{4}{|l|}{ Lags: 1} \\
\hline Null Hypothesis: & Obs & F-Statistic & Prob. \\
\hline $\log$ (MPS) does not Granger Cause $\log (\mathrm{DPS} 2)$ & 176 & 15.7095 & 0.0001 \\
\hline $\log (\mathrm{DPS} 2)$ does not Granger Cause $\log (\mathrm{MPS})$ & & 8.12729 & 0.0049 \\
\hline
\end{tabular}

\subsection{Regression Modeling Based on the Arellano-Bond Approach}

When selecting a regression model in this study we take into account the following properties of the available panel data: 1) non-stationarity, 2) the presence of both exogenous and endogenous variables, lagged variables, 3) heterogeneity due to the use of cross sections, 4) time effects. Traditional models such as OLS, fixed effects, random effects, or FMOLS are deemed inappropriate in these settings (Suwanhirunkul \& Masih, 2018). For example, the fixed effects model is based on the assumption of strict exogeneity. However, MPS_lag is an exogenous variable. Because of the correlation between the lagged dependent variable and the error term, the least squares estimates are biased (Greene, 2003). As a result, the focus of this study is diverted to dynamic data panels. In particular, the Arellano-Bond (AB) (Arellano \& Bond, 1991) estimator is selected given its capability of dealing with aforementioned data properties. Following some previous studies (e.g., Abdullah et al., 2018; Phan \& Tran, 2019; Olaniyi, 2019), we use the AB estimator, as it produces estimates with flexible assumptions. Moreover, the $\mathrm{AB}$ estimator is capable of overcoming econometric limitations, such as the problems of small samples and especially when the number of cross-sectional units is greater than the number of time periods (Olaniyi, 2019).

The AB estimator uses the first-difference transformation to get rid of the time invariant effects. As a result, stationary status is not of a concern as long as the variables are I(1). Bostanci et al. (2018) in their study stated that many studies (Anderson \& Hsiao, 1981; Baltagi, 2001; Greene, 2003), argue that dynamic panel data analysis should be utilized if the lagged dependent variable is used as an explanatory variable. According to the 
panel unit root tests we conducted above, MPS, DPS and DPO are either I(0) or I(1) processes. This satisfies the criteria of using the $\mathrm{AB}$ estimator. The approach is capable of accommodating $\mathrm{I}(0)$ and $\mathrm{I}(1)$ variables. Generally, the $\mathrm{AB}$ estimator is a good match for the data properties in this study. The panel unit roots test revealed none of the variables is a $\mathrm{I}(2)$ series, further confirming the suitability of $\mathrm{AB}$ estimator.

This study adopts a dynamic panel data model with the inclusion of control variables and time effects (see Tsionas, 2019, p. 391):

$$
\log \left(M P S_{i, t}\right)=\rho \log \left(M P S_{i, t-1}\right)+\beta_{1} \log \left(D P S 2_{i, t-1}\right)+\beta_{2} L O G S_{i, t-1}+\pi_{i}+\gamma_{t}+\varepsilon_{i, t}
$$

where $\pi_{i}$ denotes individual firm-specific effects (unobservable firm effects) to capture unobserved heterogeneities among firms, $\gamma_{t}$ are dummy variables representing the time effect, $\varepsilon_{i, t}$ is the error term (with zero mean), $i$ are cross sectional units, $t$ are time arguments, and $\rho, \beta_{1}, \beta_{2}$ are the unknown coefficients of the model.

The model is based on the transformed data (earlier we found that data transformations help reduce heteroscedasticity and make linear dependencies more pronounced, see Section 5.1.2). The use of logarithms allows the interpretation of coefficients in the form of elasticities (de Wet \& Mpinda, 2013).

We used the R statistical environment (R Core Team, 2020) to estimate the model.

In order to have consistent estimates of coefficients, this study follows the Arellano and Bond (1991) approach by adopting a linear instrumental variables technique. In order to ascertain the validity of the instruments adopted, Sargan tests of overidentifying restriction were used. The Sargan test's null hypothesis states that instruments are not correlated with error term in order to confirm that the use of the instrumental variables is appropriate and valid.

The Sargan tests indicated that we cannot reject the null hypotheses ( $p$-val=0.199, which are more than 0.05). Resultantly, our instrumental variables do not correlate with the error terms. Also, we confirmed the model does not suffer from serial correlation. The presence of 1 st degree and 2nd degree autocorrelation was tested. The $\operatorname{AR}(2)$ term appeared to be negative and insignificant ( $\mathrm{p}-\mathrm{val}=0.821$ ). According to Bostanci et al. (2018) for the Generalized Moments Estimator to be effective, it is sufficient that there be no second degree autocorrelation with reference to (Tatoğlu, 2013). Estimates of coefficients are given in Table 6. We used 'plm' R-package (Croissant \& Millo, 2008) to produce the output.

Table 6. GMM dynamic panel regression results (output from 'plm' R-package)

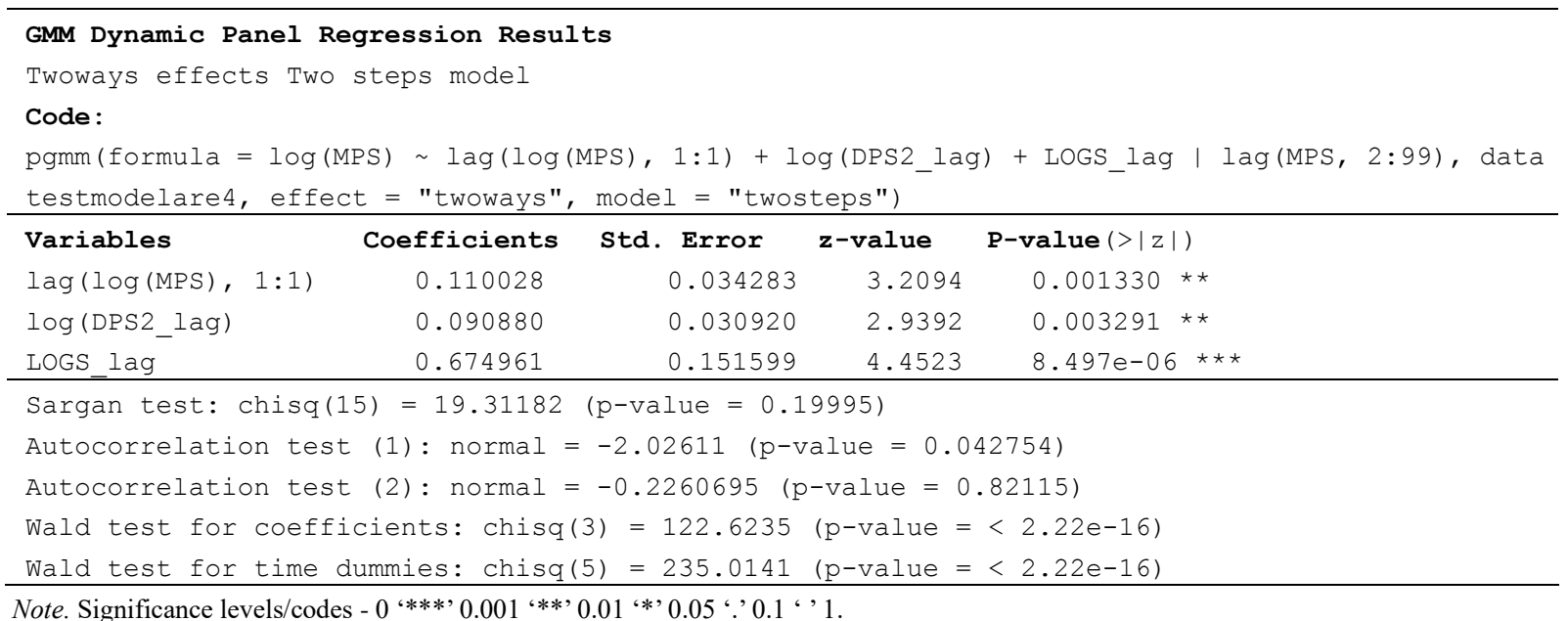

The coefficients of the model can be interpreted in terms of elasticity given the use of log variables (de Wet \& Mpinda, 2013). Resultantly, MPS_lag, DPS_lag, LOGS_lag reflected a strong positive significant relationship with MPS given the p-values in each case are less than 0.05. Interestingly, our attempts to add additional exploratory variables, such as $\log (\mathrm{DPO}), \log \left(\mathrm{EPS} \_\mathrm{lag}\right), \log \left(\mathrm{GR} \_\right.$lag $)$and $\log (\mathrm{GRA}$ lag $)$ did not lead to significant coefficients.

According to model results dividends are of an informational value and the share prices are determined by lagged Market prices, dividends, size and performance (proxied by LOGS_lag) of a firm. The results are of a 
paramount importance to investors and firms themselves to arrive at better informed decisions. The firms are hereby advised to get the right balance between disbursing dividends given the significance of the sales variable in above two models. This study shows evidence that dividends are an everlasting stimulus despite the share prices are subject to a number of external shocks. Accordingly, the firms should be careful of sustaining dividends as investors have a tendency to be driven by dividends. The results of this study are in line with initial findings of Lintner (1956) and signaling theory.

\section{Limitations and Possibilities for Further Research}

Stock market pressures and one-off shocks on share prices were not taken into account in this study. The study is focused on the cash dividend whereas scrip dividends and share repurchased are not considered despite them being identified as wealth building tools. The influence of dividends on share prices was not investigated in the context of the clientele effect. However, the results are believed to be of a fair reflection if clientele effect is given consideration.

Also, we did not carry out performance evaluation of the model we used. In fact, the choice of appropriate metrics for such evaluation is not straight-forward (see, e.g., Davydenko \& Fildes, 2013). For panel data models, due to the presence of heterogeneity, we cannot use metrics such well-known metrics as mean absolute error (MAE) or mean squared error (MSE) to measure accuracy and mean error (ME) to measure bias. For the same reason the use of metrics such as R-squared may be not desirable as well. One possible way to do this is to use metrics used in the field of forecasting. We suggest the use of metrics reflecting relative performances, such as the average relative MAE (AvgRelMAE) from (Davydenko \& Fildes, 2013) or the average relative MSE (AvgRelMSE) proposed in (Davydenko, 2012, p. 63). To report bias for panel data models, it is possible to use the average relative absolute mean error AvgRelAME proposed in (Davydenko, 2012, p 64). A set of visual tools is also available to ensure a reliable comparison of panel data models (see Davydenko et al., 2020). While theoretical considerations are important in choosing the most appropriate model, we believe empirical evaluation and comparison of alternative models using the tools mentioned will give additional insights into modelling of relevant data.

\section{Conclusions}

In this paper we explored the association between MPS and DPS using a set of statistical tools. This task is important as it investigates the short and long term impact of dividends on shares helping investors make more informed decisions. A number of studies have previously focused on the same issues. However, different countries were studied using different methods, which make it difficult to obtain a clear picture, especially with regard to the context of developing markets. Moreover, some methods used previously could pose a risk of spurious correlation, thus we focused on improved modeling techniques to obtain reliable results.

To conduct the study we used empirical data relating to Sri Lankan companies. This study is conducted with a particular regard to data properties and addressing issues like spurious correlation, endogeneity and non-stationarity, thereby selecting appropriate modeling techniques. We also conducted a thorough visual analysis of the available data in order to gain insights and detect potential data issues. We demonstrated how the EDA framework proposed by Davydenko and Charith, 2020a can be used to conduct the visual analysis of a real-world dataset. In particular, we demonstrated how data transformations can be effectively applied to financial panel data, such as MPS and DPS. Apart from the visual analysis, we used formal panel unit root tests in order to detect the presence of non-stationarity in time series. As a result of the prerequisite data analysis, we selected the Arellano-Bond (AB) approach to perform regression modelling. We found that MPS and DPS form time series having integration order less than 2. According to our knowledge, the use of the AB estimator has been explored in the Sri Lankan context, which this study one of the first studies where this particular method is applied to a Sri Lankan dataset.

The results provide high evidence for the following relationships. MPS is positively correlated with its previous values, DPS values, and lagged sales data. A short term bidirectional G-causality is revealed between MPS and DPS. These results validate some theoretical literature, such as agency theory, bird in hand theory, signaling effect and existence of clientele who prefer dividends. In conclusion, the dividends are of an informational value and influence on the share prices, specifically in the short term.

\section{References}

Abdullah, M. N., Quader, S. M., \& Saha, J. (2018). Impact of Payout Policy on Market Value. International Review of Business Research Papers, 14(1), 109-131. https://doi.org/10.21102/irbrp.2018.03.141.07

Ahmad, M. A., Alrjoub, A. M. S., \& Alrabba, H. M. (2018). The effect of dividend policy on stock price 
volatility: empirical evidence from amman stock exchange. Academy of Accounting and Financial Studies Journal, 22(2), 1-8.

Ali, S., Ishtiaq, Q., \& Naveed, M. (2011). Impact of Dividend Policy on Shareholders' Wealth: A Case of Karachi Stock Exchange. Business \& Economic Review, Institute of Management Sciences, Peshawar, Pakistan, 3(1), 106-121. https://doi.org/10.22547/BER/3.1.7

Al-Shawawreh, F. K. (2014). The impact of dividend policy on share price volatility: Empirical evidence from Jordanian stock market. European Journal of Business and Management, 6(38), 133-143.

Anderson, T. W., \& Hsiao, C. (1981). Estimation of dynamic models with error components. Journal of the American statistical Association, 76(375), 598-606. https://doi.org/10.1080/01621459.1981.10477691

Ang, J. S., \& Ciccone, S. J. (2011). Dividend Irrelevance Theory. Dividends and Dividend Policy, 11, 95-113. https://doi.org/10.1002/9781118258408.ch6

Arellano, M., \& Bond, S. (1991). Some tests of specification for panel data: Monte Carlo evidence and an application to employment equations. The Review of Economic Studies, 58(2), 277-297. https://doi.org/10.2307/2297968

Asquith, P., \& Mullins Jr, D. W. (1983). The impact of initiating dividend payments on shareholders' wealth. Journal of business, 56(1), 77-96. https://doi.org/10.1086/296187

Auret, C., \& De Villiers, J. (2000). A comparison of earnings per share and dividends per share as explanatory variables for share price. Journal for Studies in Economics and Econometrics, 24(1), 39-53.

Azhagaiah, R., \& Priya, S. (2008). The impact of dividend policy on shareholders' wealth. International Research Journal of Finance and Economics, 20(20), 180-187.

Baltagi, B. (2001). Econometric Analysis of Panel Data. John Wiley \& Sons, Chichester.

Bhattacharya, S. (1979). Imperfect information, dividend policy, and "the bird in the hand" fallacy. The bell Journal of Economics, 10(1), 259-270. https://doi.org/10.2307/3003330

Black, F. (1976). The dividend puzzle. The Journal of Portfolio Management, 2(2), 5-8. https://doi.org/10.3905/jpm.1976.408558

Black, F., \& Scholes, M. (1974). The effects of dividend yield and dividend policy on common stock prices and returns. Journal of Financial Economics, 1(1), 1-22. https://doi.org/10.1016/0304-405X(74)90006-3

Bostanci, F., Kadioglu, E., \& Sayilgan, G. (2018). Determinants of dividend payout decisions: A dynamic panel data analysis of Turkish stock market. International Journal of Financial Studies, 6(4), 93. https://doi.org/10.3390/ijfs6040093

Brennan, M. J. (1970). Taxes, market valuation and corporate financial policy. National Tax Journal, 23(4), 417-427.

Charith, K., \& Davydenko, A. (2020a). 'Colombol' dataset: Investor ratios for a cross section of Sri Lankan companies (ver 1.00) [Dataset]. Figshare. https://doi.org/10.6084/m9.figshare.13475901

Charith, K., \& Davydenko, A. (2020b, July 29-30). Is Cash Dividend an Everlasting Stimulus? Impact of Cash Dividend on Share Price of Manufacturing Companies in Sri Lanka [ePoster]. IRCUWU2020. https://doi.org/10.6084/m9.figshare.12788372

Charith, K., \& Davydenko, A. (2020c, July 29-30). Is Cash Dividend an Everlasting Stimulus? Impact of Cash Dividend on Share Price of Manufacturing Companies in Sri Lanka [Conference presentation abstract]. IRCUWU2020. https://doi.org/10.6084/m9.figshare.12788345

Croissant Y., \& Millo, G. (2008). Panel Data Econometrics in R: The plm Package. Journal of Statistical Software, 27(2), 1-43. https://doi.org/10.18637/jss.v027.i02

Davydenko, A. (2012). Integration of judgmental and statistical approaches for demand forecasting: Models and methods (doctoral dissertation). Lancaster University, UK. https://doi.org/10.13140/RG.2.2.31788.62083

Davydenko, A., \& Charith, K. (2020a, July 29-30). A Visual Framework for Longitudinal and Panel Studies (with Examples in R) [ePoster]. IRCUWU2020. https://doi.org/10.6084/m9.figshare.12749432

Davydenko, A., \& Charith, K. (2020b, July 29-30). A Visual Framework for Longitudinal and Panel Studies (with Examples in $R$ ) [Conference presentation abstract]. IRCUWU2020. https://doi.org/10.6084/m9.figshare.12749384 
Davydenko, A., \& Charith, K. (2020c, December 5). xdPlot data visualization framework. Retrieved from https://xdplot.blogspot.com/p/principles.html

Davydenko, A., \& Fildes, R. (2013). Measuring forecasting accuracy: The case of judgmental adjustments to SKU-level demand forecasts. International Journal of Forecasting, 29(3), 510-522. https://doi.org/10.1016/j.ijforecast.2012.09.002

Davydenko, A., Sai, C., \& Shcherbakov, M. (2020, September 14-16). Data Formats and Visual Tools for Forecast Evaluation in Cyber-Physical System Design [Conference Presentation]. International scientific multiconference "Cyber-physical systems design and modelling" CyberPhy-2020, Kazan, Russia. https://doi.org/10.6084/m9.figshare.12981329

De Wet, J., \& Mpinda, M. (2013). The Impact Of Dividend Payments On Shareholders Wealth: Evidence From The Vector Error Correction Model. International Business \& Economics Research Journal (IBER), 12(11), 1451-1466. https://doi.org/10.19030/iber.v12i11.8182

DeAngelo, H., \& DeAngelo, L. (2006). The irrelevance of the MM dividend irrelevance theorem. Journal of Financial Economics, 79(2), 293-315. https://doi.org/10.1016/j.jfineco.2005.03.003

Dewasiri, N., \& Banda, Y. W. (2015). Dividend Policy and Stock Price Volatility: An Error Corrected Approach. Asia-Pacific Journal of Management Research and Innovation, 11(3), 165-171. https://doi.org/10.1177/2319510X15588387

Easterbrook, F. H. (1984). Two agency-cost explanations of dividends. The American Economic Review, 74(4), 650-659.

Engle, R., \& Granger, C. (1987). Co-Integration and Error Correction: Representation, Estimation, and Testing. Econometrica, 55(2), 251-276. https://doi.org/10.2307/1913236

Fama, E. F. (1970). Efficient capital markets: A review of theory and empirical work. The Journal of Finance, 25(2), 383-417. https://doi.org/10.2307/2325486

Farrar, D. E., \& Selwyn, L. L. (1967). Taxes, corporate financial policy and return to investors. National Tax Journal, 20(4), 444-454.

Farrukh, K., Irshad, S., Shams, K. M., Ishaque, S., \& Ansari, N. Y. (2017). Impact of dividend policy on shareholders wealth and firm performance in Pakistan. Cogent Business \& Management, 4(1), 1-11. https://doi.org/10.1080/23311975.2017.1408208

Gordon, M. J. (1959). Dividends, earnings, and stock prices. The Review of Economics and Statistics, 41(2), 99-105. https://doi.org/10.2307/1927792

Gordon, M. J. (1962). The savings investment and valuation of a corporation. The Review of Economics and Statistics, 44, 37-51. http://dx.doi.org/10.2307/1926621

Greene, W. H. (2003). Econometric analysis. Pearson Education India, Delhi.

Hamid, K., Usman, K. M., \& Ghaffar, W. (2017). Juxtaposition of micro and macro dynamics of dividend policy on stock price volatility in financial sector of Pakistan:(comparative analysis through common, fixed, random and GMM effect). Journal of Accounting, Finance and Auditing Studies, 3(1), 64-79.

Harshapriya, W. (2016). The impact of dividend policy on share price volatility: Evidence from banking stocks in Colombo Stock Exchange. Staff Studies, 46(1-2), 27-67. https://doi.org/10.4038/ss.v46i1-2.4699

Hunjra, A. I., Ijaz, M., Chani, D., Irfan, M., \& Mustafa, U. (2014). Impact of dividend policy, earning per share, return on equity, profit after tax on stock prices. International Journal of Economics and Empirical Research, 2(3), 109-115.

Hussainey, K., Mgbame, C. O., \& Chijoke-Mgbame, A. M. (2011). Dividend policy and share price volatility: UK evidence. The Journal of Risk Finance, 12(1), 57-68. https://doi.org/10.1108/15265941111100076

IHS Global Inc. (2019). EViews 11 command and programming reference. Irvine: IHS Global Inc.

John, K., \& Williams, J. (1985). Dividends, dilution, and taxes: A signalling equilibrium. The Journal of Finance, 40(4), 1053-1070. https://doi.org/10.1111/j.1540-6261.1985.tb02363.x

Lashgari, Z., \& Ahmadi, M. (2014). The impact of dividend policy on stock price volatility in the Tehran stock exchange. Kuwait Chapter of the Arabian Journal of Business and Management Review, 3(10), 273. https://doi.org/10.12816/0018408 
Lintner, J. (1956). Distribution of incomes of corporations among dividends, retained earnings, and taxes. The American Economic Review, 46(2), 97-113.

Maddala, G. S., \& Wu, S. (1999). A comparative study of unit root tests with panel data and a new simple test. Oxford Bulletin of Economics and Statistics, 61(S1), 631-652. https://doi.org/10.1111/1468-0084.0610s1631

Maditinos, D. I., Sevic, Z., Theriou, N. G., \& Tsinani, A. V. (2007). Individual investors' perceptions towards dividends: The case of Greece. International Journal of Monetary Economics and Finance, 1(1), 18-31. https://doi.org/10.1504/IJMEF.2007.016023

Memon, N. A., Channa, N., \& Khoso, I. (2017). Impact of dividend policy on market prices of shares: Evidence from Pakistan. Journal of Business Strategies, 11(2), 57-72.

Miller, M. H., \& Modigliani, F. (1961). Dividend policy, growth, and the valuation of shares. The Journal of Business, 34(4), 411-433. https://doi.org/10.1086/294442

Miller, M. H., \& Rock, K. (1985). Dividend Policy under Asymmetric Information. The Journal of Finance, 40(4), 1031-1051. https://doi.org/10.2307/2328393

Modigliani, F., \& Miller, M. H. (1958). The Cost of Capital, Corporation Finance, and the Theory of Investment. American Economic Review, 48(3), 261-297.

Nirmala, P., Sanju, P., \& Ramachandran, M. (2014). Long-run causal nexus between share price and dividend. Journal of Asia Business Studies, 8(2), 136-145. https://doi.org/10.1108/JABS-09-2011-0042

Olaniyi, C. (2019). Asymmetric information phenomenon in the link between CEO pay and firm performance: An innovative approach. Journal of Economic Studies, 46(2), 306-323. https://doi.org/10.1108/JES-11-2017-0319

Persson, R. (2015). The short and long-term interdependencies between stock prices and dividends: A panel vector error correction approach (Dissertation). Uppsala University, Sweden.

Pettit, R. R. (1972). Dividend announcements, security performance, and capital market efficiency. The Journal of Finance, 27(5), 993-1007. https://doi.org/10.1111/j.1540-6261.1972.tb03018.x

Pettit, R. R. (1976). The impact of dividend and earnings announcements: A reconciliation. The Journal of Business, 49(1), 86-96. https://doi.org/10.1086/295813

Phan, T. K. H., \& Tran, N. H. (2019). Dividend policy and stock price volatility in an emerging market: Does ownership structure matter? Cogent Economics \& Finance, 7(1), 1-29. https://doi.org/10.1080/23322039.2019.1637051

Pilotte, E. (1992). Growth opportunities and the stock price response to new financing. Journal of Business Strategies, 65(3), 371-394. https://doi.org/10.1086/296576

R Core Team. (2020). R: A language and environment for statistical computing. R Foundation for Statistical Computing, Vienna, Austria. Retrieved from https://www.R-project.org/

Ross, S. A. (1977). The determination of financial structure: the incentive-signalling approach. The Bell Journal of Economics, 8(1), 23-40. https://doi.org/10.2307/3003485

Shefrin, H. M., \& Statman, M. (1984). Explaining investor preference for cash dividends. Journal of Financial Economics, 13(2), 253-282. https://doi.org/10.1016/0304-405X(84)90025-4

Solomon, E. (1963). The Theory of Financial Management. New York: Columbia University Press.

Suwanhirunkul, P., \& Masih, M. (2018). Effect of dividend policy on stock price volatility in the Dow Jones U.S. index and the Dow Jones Islamic U.S. index: Evidence from GMM and quantile regression. Munich Personal RePEc (MPRA) Paper No. 93543. Retrieved from https://mpra.ub.uni-muenchen.de/93543/

Tatoğlu, Y. F. (2013). İleri panel veri analizi stata uygulamalı. İstanbul: Beta yayınları.

Timmermann, A. (1994). Present value models with feedback: Solutions, stability, bubbles, and some empirical evidence. Journal of Economic Dynamics and Control, 18(6), 1093-1119. https://doi.org/10.1016/0165-1889(94)90049-3

Tsionas, M. (Ed.). (2019). Panel Data Econometrics: Empirical Applications. Academic Press.

Tufte, E. (2001). The Visual Display of Quantitative Information (2nd ed.). Cheshire, CT: Graphics Press.

Uusitalo, M. (2012). Compensation Committee Composition and CEO Compensation - Finnish Evidence. Aalto University, School of Economics, Department of Finance, Rahoituksen laitos. Retrieved from 
https://aaltodoc.aalto.fi/handle/123456789/3905

Walter, J. E. (1963). Dividend policy: its influence on the value of the enterprise. The Journal of Finance, 18(2), 280-291. https://doi.org/10.1111/j.1540-6261.1963.tb00724.x

Wickham, H. (2016). ggplot2: Elegant Graphics for Data Analysis. Springer-Verlag New York. https://doi.org/10.1007/978-3-319-24277-4_9

Zhu, Y., \& Tian, G. G. (2009). CEO pay-performance and board independence: The impact of earnings management in China. 4th International Conference on Asia-Pacific Financial Markets (CAFM). Seoul, Korea: Korean Securities Association.

\section{Copyrights}

Copyright for this article is retained by the author(s), with first publication rights granted to the journal.

This is an open-access article distributed under the terms and conditions of the Creative Commons Attribution license (http://creativecommons.org/licenses/by/4.0/). 